\title{
RURAL TOURISM DESTINATION COMPETITIVENES OF KUBAH NATIONAL PARK IN SARAWAK: TOURISTS' PERSPECTIVE
}

\author{
Fung-Yee Law ${ }^{1 *}$ and May-Chiun Lo ${ }^{2}$ \\ ${ }^{1}$ Institute of Social Informatics and Technological Innovations (ISITI) \\ Universiti Malaysia Sarawak, 94300 Kota Samarahan, Sarawak, Malaysia \\ ${ }^{2}$ Faculty of Economics and Business, Universiti Malaysia Sarawak, \\ 94300 Kota Samarahan, Sarawak, Malaysia \\ *Corresponding author: fy3075@gmail.com
}

Published online: 30 December 2016

To cite this article: Law, F.Y., and Lo, M.C. (2016). Rural tourism destination competitiveness of Kubah National Park in Sarawak: Tourists' perspectives. Asian Academy of Management Journal, 21(Supp. 1), 127-148. http://dx.doi.org/10.21315/ aamj2016.21.supp.1.6

To link to this article: http://dx.doi.org/10.21315/aamj2016.21.supp.1.6

\begin{abstract}
This paper argues that tourism initiatives introduced in Malaysia's rural setting lack of adequate attentions on tourists' perceptions when designing a competitive paradigm for their development and management. This paper proposes a competitive model to evaluate important factors that link to destination competitiveness. The elements of destination competitiveness investigated in this study include natural resources, range of activities, accessibility of destination and local communities. SmartPLS 2.0 (M3) is applied in this study to analyse the data collected based on path modelling and then bootstrapping. A total of 103 questionnaires collected back from Kubah National Park by using convenience sampling technique. Based on the result, natural resources, range of activities and accessibility have a significant influence on destination competitiveness. However, local communities were found not significantly influence on destination competitiveness. The results of this study are believed to contribute to tourism authorities in choosing the right tourism development paradigms in specific rural areas.
\end{abstract}

Keywords: destination competitiveness, rural tourism destination, tourists' perspective, Kubah National Park, Malaysia 


\section{BACKGROUND OF THE STUDY}

The competitiveness of tourism destinations is becoming a topic of growing interest among scholars (Mechinda, Serirat, Popaijit, Lertwannawit, \& Anuwichanont, 2010; Omerzel, 2006; Tubey \& Tubey, 2014). Because it is one of the most concerned issues in tourism industries, not least in the rural tourism sector, as increasingly domestic competition has added more pressures for rural tourism to ensure their survival. One of the reasons why destination competitiveness is receiving attention by government, industries and academia is because for rural tourism industry to be profitable and sustainable in the long run, it is crucial for rural tourism destinations to sustain their competitiveness. Tourism destination competitiveness is able to gain competitive advantages such as tourist loyalty (Reichheld \& Schefter, 2000), satisfaction (Chen, Chen \& Lee, 2011; Kozak \& Rimmington, 1999; Yoon \& Uysal, 2005) and repeat patronage by revisiting a particular destination (Chen et al., 2011; Mechinda et al., 2010; Vengesayi, 2003).

Rural tourism is now facing threats of greater competition in which rural tourism destinations sites are facing stiff competition from other celebrated tourist destinations, for example, rural tourism encounters challenges from visitors who are inclined towards visiting popular or modern tourism destinations. Undeniably, there is an increasing competition from other tourist destinations in well-known cities or reputable holiday resorts in West Malaysia such as Pulau Langkawi, Pulau Redang, Cameron Highlands, Pulau Perhentian, Pulau Tioman and etc. Because of visitors' changing expectations and the strong competition from urban tourism destinations, there is a need for entrepreneurs in rural tourism to take into account customers' needs into their competitive strategies to enable themselves to thrive in this tough environment in the coming years. Rural tourism industries need to emphasize on providing good quality of services as well as focusing in the service areas where most essential in attracting visitors for the purpose of increasing customer satisfaction and thus repeat visitation and positive word-of-mouth recommendations in order to ensuring long-lasting profitability and survival (Lee \& Kandasamy, 2011). It is obvious that if rural tourism does not achieve a high level of competitiveness, the tourism destination will be incapable of withstanding these pressures.

Kubah National Park in Kuching, Sarawak was chosen to be rural tourism destination of this study. Based on the information provided in Tourism Board official website (Sarawak Forestry Corporation, n. d.), Kubah National Park is located $21 \mathrm{~km}$ from Kuching. The Park covers an area of 2,230 hectares, and comprises the heavily forested slopes and ridges of the Serapi range. Kubah National Park comprises of rainforest with massive trees, beautiful rivers and 
waterfalls, and the richest concentration of palm species in the world. It also offers attractions such as beautiful clear watercourses which are perfect for picnicking and swimming, while the mountainous terrain and many river gullies offer visitors who have appetites for challenging trekking. Sarawak Forestry recorded Kubah as a national park with the highest number of different palm species, making Kubah probably the richest palm habitat for its size anywhere in the world. It is also possible to see animals in the wild here, particularly birds, frogs and giant squirrels. Besides that, Kubah also offers different accommodation options such as bungalows, rest houses, charlet and hostel which all fully furnished to tourists or visitors for their convenience (Sarawak Forestry Corporation, n. d.). Undeniably, Kubah National Park is one of the best rural tourism destinations. However, Kubah is not always the top option for visitors if compared to other tourism destinations. Destinations with a wealth of resources may sometimes not be as competitive as a destination with lack of resources (Tubey \& Tubey, 2014). The most important criteria for a rural tourist destination is the ability of creating and integrating valueadded products that sustain its resources to maintain market position relative to competitors (Hassan, 2000).

As aforementioned, in order to understand the competitiveness of tourism destination, both marketing scholars and practitioners need to identify and assess the relative impact of competitiveness factors. The main aim of this study is to thoroughly present a model of destination competitiveness. The paper discourses the results of survey, based on indicators associated with the model, to determine which attributes affect the competitiveness of Kubah National Park, Kuching as a tourist destination.

\section{LITERATURE REVIEW}

Several researchers (e.g., Aref \& Gill, 2009; Khound, 2013; Wani \& Shafi, 2013) explain the meaning of rural tourism by defining rural tourism as the tourism which has demonstrated the life in undistributed natural areas, art and culture, heritage and tradition in a rustic setting, and thus bringing different benefits to local communities either economically or socially, as well as enhancing the tourists' experience by interactive with local communities and other tourists in order for it to be termed as rural tourism.

Besides, the Rural Tourism Master Plan has also defined rural tourism as:

'tourism that provides opportunities to visitors to visit rural areas and rural attractions, and to experience the culture and heritage 
of Malaysia, thereby providing socio-economic benefits for local communities...the proximity of many of these rural areas to the hinterland of jungle and rainforest also offers visitors an opportunity to extend their holiday and enjoy those unique natural resources' (RTMP, 2001: p. 22).

Rural tourism in this study is defined as a rustic tourist destination which is largely dependent on natural environment, and it is engaged with various forms of local activities based on preservation of historical heritage, custom and traditions, as well as different of arts and cultures of local communities that enables it to create natural experiences for the tourists during their visits (Ramakumar \& Rajashree, 2008). Past researchers (e.g., Chen \& Tsai, 2007; Dmitrović, Cvelbar, Kolar, Brencic, Ograjenšek, \& Žabkar, 2009; Huang, 2011; Jamaludin, Johari, Aziz, Kayat, \& Yusof, 2012; Kumra, 2008; Rajesh, 2013; Zhu, 2011) have never excludes service quality issues in tourism area. They addressing a good quality of tourism destination is one of the most important components to gain customer satisfaction (e.g., Said, Shuib, Ayob, \& Yaakob, 2013; Shonk, 2006) and stand a long-lasting position in today's high competitive business environments.

\section{Tourism Destination Competitiveness}

The concepts of destination competitiveness were proved to be very complicated and broad. There is no clear definition or model has yet been developed, despite past discussions on competitiveness (Dwyer \& Kim, 2003; Wilde \& Cox, 2008). The most acceptable definition of destination competitiveness is defined by Dwyer and Kim (2003) and adopted by many researchers (e.g. Dupeyras \& MacCallum, 2013; Goffi, 2013; Marku, 2014; Komppula, 2014; Omerzel, 2006), who explained the meaning of destination competitiveness as a critical component that appears to be linked to the destination's ability in delivering goods and services superior than other destinations and the goods and services were evaluated as important tourism experiences by tourists. Destination competitiveness is also defined by Hassan (2000) as the ability of a destination to maintain its market position relative to competitors by creating value added products and integrating all productivity levels of various components of tourism industry to sustain its resources. It is proven that competitive level of a destination factors affects the attractiveness of a destination (Croes, 2010; Dwyer, Forsyth \& Rao, 2000a; Dwyer \& Kim, 2003; Perles-Ribes, Ramón-Rodríguez \& Sevilla-Jiménez, 2014; Tsai, Song, \& Wong, 2009; Wilde \& Cox, 2008). This research adopts a model representing some attributes of destination competitiveness based on the works of Dwyer and Kim (2003), who describe tourism destination competitiveness as natural resources, range of activities, accessibility of destination and local communities. This study 
attempts to conduct an empirical analysis on Kubah National Park, Kuching Sarawak as a tourist destination.

\section{Natural Resources}

Natural resources are the primary elements of destination appeal and are considered as the key drivers for gaining attention from tourists (Ross \& Iso-Ahola, 1991). Natural resources of a destination include cleanliness of destination, unspoiled nature, richness of flora and fauna and comfortable climate, which considered as the main attractions vital for many forms of tourism and tourists' satisfaction (Buckley, 1994; Heath, 2003). Dwyer and Kim (2003) indicate that natural attractions of a destination together with the environmental framework can used to reflect whether tourists enjoy the destination or otherwise. Dupeyras and MacCallum (2013) indicate that a successful tourism destination has the ability to provide unique experiences to tourists which includes natural resources. Moreover, destinations with recognised world heritage status have the competitive advantage over other destination to attract tourists. Accordingly, maintaining a high level of attractive natural environment has to be a primary concern for maintaining competitiveness (Inskeep, 1991). Many authors (Cracolici, Rietveld \& Nijkamp, 2006; Gartner, 2014; Hassan, 2000; Middleton, 1997; Mihaliç, 2000, 2013) suggest that the quality of natural attractions is part of quality destination and it can be a determinant for tourism destination competitiveness (Ritchie \& Crouch, 1993). Therefore, as discussed above, the following hypothesis is developed:

H1: There is a significant relationship between natural resources and destination competitiveness.

\section{Range of Activities}

A range of activities is defined as variety of attractions conducted in the destination area by an event organizer or management to reach some specific outcomes (Parahiyanti \& Hussein, 2015). These include recreation and sports facilities, facilities for special interest visitors such as adventure, ecotourism, cultural/ heritage tourism and biking trails (Mechinda et al., 2010). Generally, outdoor activities or events were conducted for visitors or together with local communities as a part of social interaction with the local communities. Sometimes, an event or some activities that are conducted can be used as a tool to increase a destination's reputation or destination awareness and destination branding. An event or activity not only concerned in mega events, but also a local event activities which are based on needs of tourists to provide entertainment to them (Etiosa, 2012). Some of activities or events are basically created in order to fulfill the demands of visitors 
who are seeking for adventures at the destination (Hossain, 2006). These types of activities or events are believed to contribute contribution in enhancing tourists' arrival and increase destination competitiveness as well (Ayikoru; 2015; Crouch, 2001; Presenza, Sheehan \& Ritchie, 2005). Therefore, as discussed above, the following hypothesis is developed:

H2: There is a significant relationship between range of activities and destination competitiveness.

\section{Accessibility}

Accessibility quality is defined as the availability of customers in reaching the destination such as traffic flow, parking facilities, convenience of local transportation, availability of destination information and easy connections from destination to airports, public transport terminals, and freeways (Chi \& Qu; 2008; Getz, 1997). As it is a known fact that there are many sub-sectors in tourism field such as destinations, venue, accommodation, attractions, various transport modes, attractions, personnel who provide services and etc (Fundosa Accessibility SA Final Report, 2009). A good quality accessibility of destination is to have the ability of the destination in providing the appropriate or variety of access for tourists for them to get into a geographical location and during their visitation at a particular destination with ease (Aguila \& Ragot, 2014; Hall, 2004). Mill and Morrison (1992) indicate that destination accessibility can be one of determinants to affect destination competitiveness. This is in line with Edwards (1993)'s study revealed that a long-haul tourist destinations was examined on the basis of how accessibility of destination for tourists. A good accessibility quality of a destination or within a destination area has the potential to raise the destination's capacity in attracting new markets, enhance the visitor's experience towards the destination and even can encourage a more sustainable travel between the visitor's home and destination (Guiver \& Stanford, 2014). A market survey conducted by The Commonwealth Government's White Paper (2003) identifies that accessible tourism destination always play an important part of niche experiences for tourists. McKercher, Packer, Yau, and Lam (2003) also affirm that visitors are most satisfied when the information of a destination is accessible and the location of accommodation is highly accessible. Therefore, as discussed above, the following hypothesis is developed:

H3: There is a significant relationship between accessibility of destination and destination competitiveness. 


\section{Local Communities}

Until recently, most researches focused for the factors that influence tourism caused by industries, however there is lack of researches that highlight how local communities perceptions and attitudes can affect the image of destination for visitors (Murphy, 1985; Zhang, Inbakaran \& Jackson, 2006). Basically in this study, local community is a group of people sharing the boundaries in an area of tourism (Abas \& Mohd Hanafiah, 2014). In rural tourism context, local communities play a vital role in tourism development as sometimes they are regarded as "service supplier' which can influence on the total number of tourist's arrival. Therefore, the hospitality of local communities towards tourists has been recognized as being crucial for a successful tourism destination and one of the important factors that will influence visitors to return to a destination or to recommend that destination to others (Lawson, Merrett \& William 1996; Thyne, Lawson \& Todd, 2006). Hospitality relates to the perceived friendliness of the community towards tourists whereby it consists of the warmth of reception by local residents; the willingness of residents to provide information to tourism; their attitudes towards tourists and the tourism industry (Dwyer \& Kim, 2003). Furthermore, these tourists may promote their impressions, feelings and attitudes of the destination among to their families, friends and colleagues by sharing their travel experiences with them. All these are likely to affect the destination's ability to attract return visitors as well as to generate new visitors (Zhang et al., 2006). Therefore, as discussed above, the following hypothesis is developed:

H4: There is a significant relationship between local communities and destination competitiveness.

\section{DESCRIPTION OF SAMPLE AND METHODOLOGY}

In this study, Kubah National Park is chosen as the research site since it is one of the popular rural tourism destinations in Sarawak. Additionally, the ability of the Kubah National Park to create and integrate value-added products that sustain its resources to maintain market position relative to competitors and this place is potentially gaining its reputation as a tourist destination. Both local and foreign tourists who have visited these tourism destinations or visiting these tourism places are the respondents. They are requested to complete a questionnaire that contains measures of the construct. It is important to note that, based on the rule of thumb of sample size by Hair, Hult, Christian, Ringle, and Sarstedt, (2013) the sample size 
is 10 to 15 subjects per variable. In this study, 5 variables are identified. Thus, the minimum sample size was needed in this study to be minimum of 50 respondents. However, Hair, Anderson, Tatham, and Black (1998) also recommended a sample size of more than 100 to produce more reliable results. Therefore, a total of 103 questionnaires were collected from tourists who are visiting or have visited Kubah National Park by using convenience sampling technique which can get a gross estimate of the results without incurring the cost or times require.

In order to access the research model developed, SmartPLS 2.0 (M3) (Chin, 1998a, b, 2010) is applied in this study. It is used to analyse the data collected based on path modelling and then the bootstrapping (Chin, 1998a,b; Gudergan, Ringle, Wende \& Will, 2008; Tenenhaus, Vinzi, Chatelin, \& Lauro, 2005; Wetzels, Schroder \& Oppen, 2009). Gustafsson and Johnson (2004) suggested that PLS is a useful tool to test with structural equation models that have latent variables and cause-andeffect relationships. It is supported in Gudergan et al. (2008)' study by state that, for the researcher who study on cause and effect relationship, PLS is a sustainable technique to evaluate fore-mentioned relationship especially in intricate business research. A total of 500 re-samples were used to generate the standard error of the estimate and t-values.

\section{Assessment of the Measurement Model}

Structural equation modelling analysis depends on two methods which are measurement model and structural model analysis (Anderson \& Gerbing, 1988). The measurement model is mainly for assessing the model validity and the items' reliability. At first, confirmatory factor analysis (CFA) was conducted in this study in order to access reliability, convergent validity and discriminant validity of the scales. Table 1 and 2 shows the most of the items loading were exceeded 0.5 (significant at $\mathrm{p}<0.01$ ) (Hair, Black, Babin \& Anderson, 2010) and all Average Variance Extracted (AVEs) larger than 0.5 (Fornell and Bookstein, 1982; Bagozzi \& Yi, 1988). Besides, all the Composite Reliability (CRs) were more than 0.7 (Gefen, Straub, \& Boudreau, 2000) as showed in the Table 1. Similarly, all the value of Cronbachs Alpha exceeded 0.7 (Nunnally, 1978), which means the internal reliability of items is achieved. Apart from that, the square root of the AVE was tested against the intercorrelations of the construct with the other constructs in the model to ensure discriminant validity (Chin, 1998a,b, 2010; Fornell \& Larcker, 1981) and all the square root of the AVE exceeded the correlations with other variables (Table 2). Thus, the measurement model was considered satisfactory with the evidence of adequate reliability, convergent validity, and discriminant validity. 
Table 1

Results of Measurement Model

\begin{tabular}{|c|c|c|c|c|c|}
\hline Model Construct & Measurement Item & Cronbachs Alpha & Loading & $\mathrm{CR}^{\mathrm{a}}$ & $\mathrm{AVE}^{\mathrm{b}}$ \\
\hline \multirow[t]{7}{*}{ Natural Resources } & NatuRes_01 & 0.882 & 0.763 & 0.902 & 0.570 \\
\hline & NatuRes_02 & & 0.765 & & \\
\hline & NatuRes_03 & & 0.734 & & \\
\hline & NatuRes_04 & & 0.793 & & \\
\hline & NatuRes_05 & & 0.790 & & \\
\hline & NatuRes_06 & & 0.800 & & \\
\hline & NatuRes_07 & & 0.621 & & \\
\hline \multirow[t]{4}{*}{ Range of activities } & Activities_26 & 0.739 & 0.580 & 0.830 & 0.554 \\
\hline & Activities_28 & & 0.753 & & \\
\hline & Activities_29 & & 0.741 & & \\
\hline & Activities_30 & & 0.875 & & \\
\hline \multirow[t]{5}{*}{ Accessibility } & Access_51 & 0.882 & 0.776 & 0.914 & 0.681 \\
\hline & Access_52 & & 0.793 & & \\
\hline & Access_53 & & 0.889 & & \\
\hline & Access_54 & & 0.801 & & \\
\hline & Access_55 & & 0.862 & & \\
\hline \multirow[t]{6}{*}{ Local Communities } & LocalComm_56 & 0.932 & 0.914 & 0.946 & 0.744 \\
\hline & LocalComm_57 & & 0.869 & & \\
\hline & LocalComm_58 & & 0.887 & & \\
\hline & LocalComm_59 & & 0.841 & & \\
\hline & LocalComm_60 & & 0.816 & & \\
\hline & LocalComm_61 & & 0.846 & & \\
\hline \multirow{9}{*}{$\begin{array}{l}\text { Destination } \\
\text { Competitiveness }\end{array}$} & DestCompe_62 & 0.881 & 0.734 & 0.905 & 0.516 \\
\hline & DestCompe_63 & & 0.825 & & \\
\hline & DestCompe_64 & & 0.777 & & \\
\hline & DestCompe_65 & & 0.675 & & \\
\hline & DestCompe_68 & & 0.663 & & \\
\hline & DestCompe_71 & & 0.650 & & \\
\hline & DestCompe_72 & & 0.742 & & \\
\hline & DestCompe_73 & & 0.733 & & \\
\hline & DestCompe_74 & & 0.642 & & \\
\hline
\end{tabular}

Note:

${ }^{\text {a }}$ Composite reliability $(\mathrm{CR})=$ (square of the summation of the factor loadings $) /$ \{ (square of the summation of the factor loadings $)+$ (summation of error variances $)\}$.

${ }^{\mathrm{b}}$ Average variance extracted $(\mathrm{AVE})=$ (summation of the square of the factor loadings $) /$ \{summation of the square of the factor loadings $\}+$ (summation of error variances $)\}$. 
Table 2

Discriminant Validity of Construct

\begin{tabular}{lccccc}
\hline \multicolumn{1}{c}{ Constructs } & Accessibility & $\begin{array}{c}\text { Destination } \\
\text { Competitiveness }\end{array}$ & $\begin{array}{c}\text { Local } \\
\text { Communities }\end{array}$ & $\begin{array}{c}\text { Natural } \\
\text { Resources }\end{array}$ & $\begin{array}{c}\text { Range of } \\
\text { Activities }\end{array}$ \\
\hline Accessibility & 0.825 & & & & \\
$\begin{array}{l}\text { Destination } \\
\text { Competitiveness }\end{array}$ & 0.595 & 0.718 & & & \\
Local Communities & 0.481 & 0.439 & 0.863 & & \\
Natural Resources & 0.257 & 0.345 & 0.224 & 0.755 & \\
Range of Activities & 0.088 & 0.471 & 0.076 & 0.165 & 0.744 \\
\hline
\end{tabular}

Note: Diagonals represent the square root of the average variance extracted while the other entries represent the correlations.

\section{Assessment of the Structural Model}

After the adequate reliability, convergent validity, and discriminant validity are confirmed in the model, next step is to test the hypotheses. The visual results and detailed results are indicated in Figure 2 and Table 3 respectively. Natural resources $(\beta=0.127, t=1.791)$, range of activities $(\beta=0.398, t=5.271)$, and accessibility $(\beta=0.449, t=4.289)$ are significantly related to destination competitiveness whereas local communities $(\beta=0.164, t=1.589)$ is not significant predictor of destination competitiveness. Therefore, hypothesis 1, hypothesis 2 and hypothesis 3 are supported while hypothesis 4 is not supported. The $\mathrm{R}^{2}$ value is 0.579 which indicates that $58 \%$ of the variance in the destination competitiveness can be explained by all the four constructs. The most significant predictor is range of activities, followed by accessibility and natural resources.

Table 3

Path Coefficients and Hypothesis Testing

\begin{tabular}{|c|c|c|c|c|}
\hline Hypothesis & Relationship & Std. Beta & $\mathrm{t}$-value & Decision \\
\hline H1 & $\begin{array}{l}\text { Natural Resources -> Destination } \\
\text { Competitiveness }\end{array}$ & 0.127 & $1.791 *$ & Supported \\
\hline $\mathrm{H} 2$ & $\begin{array}{l}\text { Range of Activities -> Destination } \\
\text { Competitiveness }\end{array}$ & 0.398 & $5.271 * *$ & Supported \\
\hline $\mathrm{H} 3$ & $\begin{array}{l}\text { Accessibility -> Destination } \\
\text { Competitiveness }\end{array}$ & 0.449 & $4.289 * *$ & Supported \\
\hline $\mathrm{H} 4$ & $\begin{array}{l}\text { Local Communities -> Destination } \\
\text { Competitiveness }\end{array}$ & 0.164 & 1.589 & Not Supported \\
\hline
\end{tabular}

Note: $* * p<0.01, * p<0.05$ 


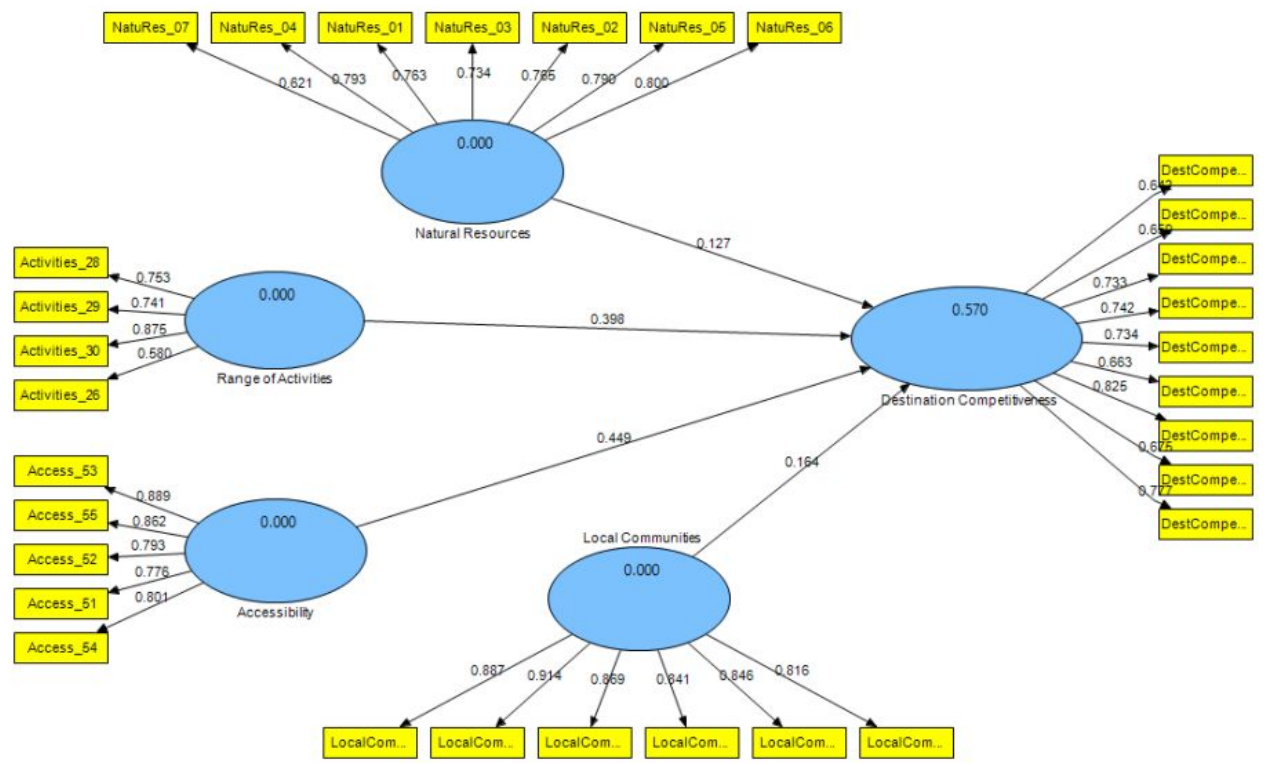

Figure 1. Results of the Path Analysis

\section{FINDINGS}

This study sets out is mainly to analyse the competitiveness of Kubah National Park as a tourist destination. Following the review of literature, the four main variables in this study are natural resources, range of activities, accessibility and local communities. The constructs of this study which are the four main variables have been examined and are well publicised over recent years. Unsurprisingly, based on the results, natural resources, range of activities and accessibility significantly influence destination competitiveness and the results of this study is in line with past studies (e.g., Kozak, 1999; Hallmann, Müller \& Feiler, 2014; Ritchie \& Crouch, 2010).

Range of activities is regarded as the most significant influence in destination competitiveness $(t=5.271)$. Ritchie and Crouch (2010) posit that the activities dimension of destination attractiveness appears to be growing in importance as the tourists are increasingly seeking new experiences that are highly exciting. A range of activities are able to identify opportunities to bring together local residents and tourists to celebrate the unique and special features of a destination. Varieties of activities in destinations successfully attracted more tourists and also they can influence tourists' destination choice. The next variable, accessibility of destination 
also significantly influence destination competitiveness $(\mathrm{t}=4.289)$. The result is supported by past studies (e.g., Al-Ababneh, 2013; Ali \& Howaidee, 2012; Kozak et al., 2009; Ritchie \& Crouch, 2010). The ease of gaining transportation access into and around a destination is found to be an important determinant attribute as well. Where accessibility is difficult (whether it is due to lengthy travel times, high costs, entry barriers and formalities, unpleasant travel connections or schedules) it can decrease willingness of tourists visit the place (Ritchie \& Crouch, 2010). Kozak, Baloğlu and Bahar (2009) concur that a destination's resources are hardly relevant to the issue of competitiveness unless they are accessible to potential tourists and tourism operators alike.

This study also found that natural resources are significantly linked to destination competitiveness (1.791). The result is also in congruent with previous studies (e.g. Chen, 2001; Crouch, 2011; Mihalič, 2000). For many destinations, the natural environment is one of the primary attractions for leisure visitors. A wide range of recreational, activity based, educational, cultural activities and experiences, can be accessed by visitors in natural and protected areas. It provides a powerful attracting force for the prospective tourist (Murphy, Pritchard \& Smith 2000), and thus enhances its competitiveness level.

However, local communities were found not to have a significant influence on destination competitiveness (1.589). The result is in contrast to Omerzel's study (2006) and Kozak et al., (2009) which indicate that the hospitality of local residents was rated highly by tourists. The possible explanation of the result is tourists who are visiting to Kubah National Park are seeking for a variety of landscape types and climates, and there are numerous options for natural activities in all seasons. As Huh (2002) indicated that there is a rising trend among travelers that enjoy the unique rural life which has the richness in term of natural resources and variety of nature exploring activities. As aforementioned, the unique selling proposition in Kubah National Park are more of unspoiled nature environment and different types of natural activities such as camping, hiking, jungle trekking, swimming and so on. Kubah National Park is able to market itself by creating an image of peace and quiet in natural settings and richness of unspoiled nature. This creates an image of a relaxing atmosphere for the destinations for tourists to enjoy peace, nature and relaxing. However, Kubah National Park does not offer any cultural activities or events or cultural attractions which these activities are normally provided by local residents. Due to this reason, local residents mostly are not a major concern or main motive for them when they plan to having a unique travelling experience in Kubah National Park. 


\section{CONCLUSION, IMPPLICATIONS AND SUGGESTIONS}

Past researchers (Crouch, 2011; Dwyer \& Kim, 2003; Gomezelj \& Mihalič, 2008; Hallmann, Müller, Feiler, Breuer, \& Roth, 2012; Hudson, Ritchie \& Timur, 2004) have investigated the supply side of the destination, but the demand side of destination or tourist's perspectives have not been thoroughly study (e,g., Akroush, Jraisat, Kurdieh, AL-Faouri \& Qatu, 2016; Formica, 2004; Yoon, 2002). Clearly, consumers play a main role in the tourism system and their perspectives are regarded as a key resource and one of the competitive advantages for rural tourism business (Pikkemaat \& Müller, 2008). Barsky and Nash (2002) indicate that the more information providers gain from consumers, the more quality of experiences and successful tourism products they can offer to consumers. Bieger (2005) highlights the importance of tourists' perspective in the tourism production and consumption process and the need for destinations' unique selling propositions. Therefore, the main purpose of the study is to empirically test and identify which elements influence destination competitiveness in Kubah National Park, Kuching from demand side.

On the basis of obtained empirical results from this study, it is suggested that some improvements should be made to Kubah National Park to become a more competitive rural tourism destination. The fundamental principle of the destination management process is that it involves bringing together stakeholders to clearly articulate the strategic direction and actions for the development, marketing and management of a destination for the future. All kinds of management activities and actions should includes preservation of natural resources, creating and integrating value in tourism activities and enhancing accessibility of destination so that Kubah National Park as a tourist destination to achieve better competitive market position. Moreover, the model allows destination competitiveness to be monitored over time. This can provide a moving picture of destination competitiveness at different points in time especially for the environment and policy maker who want to deliver maximum competitive advantages that supporting long-term sustainable tourism growth.

Apart from that, the implication for this study can be set as a guideline for the rural tourism destination to understand their current and desired tourists' preferences clearly which helps them in developing, managing and marketing a destination to ensure both short-term and long-term sustainability goals are achievable. It is essential for stakeholders or policy markers understand a destination target market's behaviors, characteristics, decision making process, needs and preferences are 
vital in developing suitable strategies for destination development and market. Moreover, the results of this study can help tourism authorities in choosing the right tourism development paradigms in specific rural areas. For instance, customisation and diversification of activities are a priority in delivering quality tourism experiences which meet or exceed visitors' expectations. It is a key to enhance the accessibility of destination by providing more transportation modes. A good infrastructure such as road or railway cannot be neglected also since natural resource is also an important element, such concerns have to put in preservation of natural resources and to ensure constant environmental monitoring of destination.

The findings are limited to the competitiveness attributes included in the study and for future research a qualitative study would help reveal some other components of tourist destination competitiveness. Therefore, it is suggested that future researches can broader the data set to offer further valuable insights by combining several study sites. Besides that, the competitiveness model should focus on the importance of different attributes which could be improved by seeking to better quantitatively measure and the relative importance of various factors determining the destination competitiveness. Additionally, future researches can focuses on both direct measures and indirect measures (e.g., market share, profitability and any other financial indicators) on destination competitiveness to form a more integrated and comprehensive destination competitiveness model. Another limitation of the study is that the results may not be generalise over other rural tourism destinations. Future research would aim to replicate this study by using different samples and extend the study scope by including multiple destinations and nationalities. It is a need also to conduct more valid assessment of tourist destination competitiveness by comparing the destination with more than two destinations and examine it from multiple nationalities' perspective.

\section{ACKNOWLEDGEMENT}

The funding of this research is obtained through research grants from the Ministry of Higher Education, Malaysia and Universiti Malaysia Sarawak under grant no of [NRGS/1091/2013 (05)JPT.S(BPKI)2000/04/07/03].

\section{REFERENCES}

Abas, A. S., \& Mohd Hanafiah, M. H. (2014). Local community attitudes towards tourism development in Tioman Island. 6th Tourism Outlook Conference. Paper Tourism, Leisure and Global Change, 1, 135-147. 
Aguila, G. M., \& Ragot, R. (2014). Ecotourism industry in Ilijan Batangas City, Philippines: Assessing its effects as a basis of proposed tourism development plan. Quarterly Journal of Business Studies, 1(1), 24-35.

Akroush, M. N., Jraisat, L. E., Kurdieh, D. J., AL-Faouri, R. N., \& Qatu, L. T. (2016). Tourism service quality and destination loyalty-the mediating role of destination image from international tourists' perspectives. Tourism Review, 71(1).

Al-Ababneh, M. (2013). Service quality and its impact on tourist satisfaction. Interdisciplinary Journal of Contemporary Research in Business, 4(12), 164-177.

Ali, J. A., \& Howaidee, M. (2012). The impact of service quality on tourist satisfaction in Jerash. Interdisciplinary Journal of Contemporary Research in Business, 3(12), 164-187.

Anderson, J. C., \& Gerbing, D. W. (1988). Structural equation modeling in practice: A review and recommended two-step approach. Psychological Bulletin, 103(3), 411-423. http://dx.doi.org/10.1037/0033-2909.103.3.411

Aref, F., \& Gill, S. S. (2009). Rural tourism development through rural cooperatives. Nature and Science, 7(10), 68-73.

Ayikoru, M. (2015). Destination competitiveness challenges: A Ugandan perspective. Tourism Management, 50, 142-158. http://dx.doi.org/10.1016/j.tourman.2015. 01.009

Bagozzi, R. P., \& Yi, Y. (1988). On the evaluation of structural equation models. Journal of the Academy of Marketing Science, 16(1), 74-94. http://dx.doi.org/10.1007/ BF02723327

Barsky, J., \& Nash, L. (2002). Evoking emotion: affective keys to hotel loyalty. The Cornell Hotel and Restaurant Administration Quarterly, 43(1), 39-46. http://dx.doi.org/10.1016/S0010-8804(02)80007-6

Bieger, T. (2005). Management von destinationen. München: Oldenbourg.

Buckley, R. (1994). A framework for ecotourism. Annals of Tourism Research, 21(3), 661-669. http://dx.doi.org/10.1016/0160-7383(94)90126-0

Chen, C. M., Chen, S. H., \& Lee, H. T. (2011). The destination competitiveness of Kinmen's tourism industry: Exploring the interrelationships between tourist perceptions, service performance, customer satisfaction and sustainable tourism. Journal of Sustainable Tourism, 19(2), 247-264. http://dx.doi.org/10.1080/09669582.2010 .517315

Chen, C. F., \& Tsai, D. (2007). How destination image and evaluative factors affect behavioral intentions. Tourism Management, 28, 1115-1122. http://dx.doi. org/10.1016/j. tourman.2006.07.007

Chen, J. S. (2001). A case study of Korean outbound travelers' destination images by using correspondence analysis. Tourism Management, 22, 345-350. http://dx.doi. org/10.1016/S0261-5177(00)00066-2

Chi, C., \& Qu, H. (2008). Examining the structural relationship of destination image, tourist satisfaction and destination loyalty: An integrated approach. Tourism Management 29(4), 624-636. http://dx.doi.org/10.1016/j.tourman.2007.06.007

Chin, W. W. (1998a). Issues and opinion on structural equation modeling. MIS Quarterly, 22(1), VII-XVI. 
Chin, W. W. (1998b). The partial least squares approach for structural equation modeling In G. A. E. Marcoulides (Ed.), Modern methods for business research, Methodology for business and management (pp. 295-336). Mahwah, NJ, US: Lawrence Erlbaum Associates Publishers.

Chin, W. W. (2010). How to write up and report PLS Analyses. In V. E. Vinzi, W. W. Chin, J. Henseler, \& H. Wang (Eds.), Handbook of partial least squares: Concepts, methods and application (pp. 645-689). New York: Springer. http://dx.doi. org/10.1007/978-3-540-32827-8 29

Commonwealth Department of Industry Tourism and Resources. (2003). Tourism white paper -the medium to long-term strategy for tourism. Canberra: CDITR.

Cracolici, M. F., Rietveld, P., \& Nijkamp, P. (2006). Assessment of tourist competitiveness by analysing destination efficiency. Tinbergen Institute Discussion Paper, No. 06097/3. http://dx.doi.org/10.2139/ssrn.942729

Croes, R. (2010). Small island tourism competitiveness: Expanding your destination" $s$ slice of paradise. Rosen College of Hospitality Management, Lecture notes, 1-32.

Crouch, G. I. (2001). Developing Operational Measures for the Components of a Destination Competitiveness/Sustainability Model: Consumer versus Managerial Perspectives. In J. A. Mazanec, G. I. Crouch, J. R. Brent Richie, \& A. G. Woodside (Eds). Consumer psychology of tourism, hospitality, and leisure (pp. 1-17). Wallingford: CABI Publishing.

Crouch, G. I. (2011). Destination competitiveness: An analysis of determinant attributes. Journal of Travel Research, 50, 27-45. http://dx.doi.org/10.1177/ 0047287510362776

Dmitrović, T., Cvelbar, L. J., Kolar, T., Brencic, M. M., Ograjenšek, I., \& Žabkar, V. (2009). Conceptualizing tourist satisfaction at the destination level. International Journal of Culture, Tourism and Hospitality Research, 3(2), 116-126. http://dx.doi.org/10.1108/17506180910962122

Dunn, R., \& Iso-Ahala, S. (1991). Sightseeing tourists" motivations and satisfaction. Annals of Tourism Research, 18(2), 226-237. http://dx.doi.org/10.1016/01607383(91)90006-W

Dupeyras, A., \& MacCallum, N. (2013). Indicators for measuring competitiveness in tourism: A Guidance document. OECD Tourism Papers, 2013/02, OECD Publishing. http://dx.doi.org/10.1787/5k47t9q2t923-en

Dwyer, L., Forsyth, P., \& Rao, P. (2000a). The price competitiveness of travel and tourism: A comparison of 19 destinations. Tourism Management, 21(1), 9-22. http:// dx.doi.org/10.1016/S0261-5177(99)00081-3

Dywer, L., \& Kim, C. (2003). Destination competitiveness: A model and determinants. Current Issues In Tourism, 6(5), 369-414. http://dx.doi.org/10.1080/ 13683500308667962

Edwards, A. (1993) Price Competitiveness of holiday destinations: Costs from European travellers II (Research Report). London: The Economist Intelligence Unit. 
Etiosa, O. (April 2012). The impacts of event tourism on host communities: The city of Pietarsaari (Unpublished thesis). Degree programme in Tourism, Central Ostrobothnia University of Applied Sciences, Unit for Technology and Business, Kokkola-Pietarsaari. Retrieved from https://publications.theseus.fi/bitstream/ handle/10024/43714/omoregie_etiosa.pdf?sequence $=1$

Formica, S. (2004). Destination attractiveness as a function of supply and demand interaction (Doctoral Dissertation). Retrieved March 4, 2016 from https://theses.lib.vt.edu/ theses/available/etd-11142000-15560052/unrestricted/DissertationDefense.pdf

Fornell, C., \& Bookstein, F. L. (1982). Two structural equation models: LISREL and PLS applied to consumer exit-voice theory. Journal of Marketing research, 19(4), 440-452. http://dx.doi.org/10.2307/3151718

Fornell, C. \& Larcker, D. F. (1981). Evaluating structural equation models with unobservable variables and measurement error. Journal of Marketing Research, 18(1), 39 -50. http://dx.doi.org/10.2307/3151312

Fundosa Accessibility SA Final Report. (2009). Study of access Requirements related quality norms in European tourism. Vía Libre, SA: Ambrose, I., \& Vicens, C. Retrieved from http://www.accessibletourism.org/?i=enat.en. reports. 1488.

Gartner, W. C. (2014). Brand equity in a tourism destination. Place Branding and Public Diplomacy, 10(2), 108-116. http://dx.doi.org/10.1057/pb.2014.6

Gefen, D., Straub, D., \& Boudreau, M. C. (2000). Structural equation modeling and regression: Guidelines for research practice. Communications of the association for information systems, 4(7), 1-77.

Getz, D. (1997). Event management \& event tourism. Elmsford, NY: Cognizant Communication Corporation.

Goffi, G. (2013). A model of tourism destinations competitiveness: The case of the Italian destinations of excellence. en Anuario Turismo y Sociedad, XIV, 121-147.

Gomezelj, D. O., \& Mihalič, T. (2008). Destination competitiveness-Applying different models: The case of Slovenia. Tourism management, 29(2), 294-307. http:// dx.doi.org/10.1016/j.tourman.2007.03.009

Gudergan, S. P., Ringle, C. M., Wende, S., \& Will, A. (2008). Con-firmatory tetrad analysis in PLS path modeling. Journal of Business Research, 61(12), 1238-1249. http://dx.doi.org/10.1016/j.jbusres.2008.01.012

Guiver, J., \& Stanford, D. (2014). Why destination visitor travel planning falls between the cracks. Journal of Destination Marketing \& Management, 3(3), 140-151. http://dx.doi.org/10.1016/j.jdmm.2013.11.005

Gustafsson, A., \& Johnson, M. D. (2004). Determining attribute importance in a service satisfaction model. Journal of Service Research, 7(2), 124-141. http://dx.doi. org/10.1177/1094670504268453

Hair, J. F., Anderson, R. E., Tatham, R. L. \& Black, W. C. (1998). Multivariate data analysis, 5, 87-135.

Hair, J. F, Black, W. C., Babin, B. J., \& Anderson, R. E. (2010). Multivariate data analysis ( $7^{\text {th }}$ edition). USA: Pretice-Hall International. 
Hair, J. F., Hult, G. T. M., Christian, M. Ringle, \& Sarstedt, M. (2013). A primer on partial least squares strucutral equation modeling PLS-SEM. Sage Publications.

Hall, C. M. (2004). Space-time accessibility and the tourist area cycle of evolution: The role of geographies of spatial interaction and mobility in contributing to an improved understanding of tourism, In R. Butler (Ed.), The tourism area life cycle: Conceptual and theoretical issues (pp. 83-100). Clevedon: Channelview Publications.

Hallmann, K., Müller, S., \& Feiler, S. (2014). Destination competitiveness of winter sport resorts in the Alps: how sport tourists perceive destinations? Current Issues in Tourism, 17(4), 327-349. http://dx.doi.org/10.1080/13683500.2012.720247

Hallmann, K., Müller, S., Feiler, S., Breuer, C., \& Roth, R. (2012). Suppliers' perception of destination competitiveness in a winter sport resort. Tourism Review, 67(2), 13-21. http://dx.doi.org/10.1108/16605371211236105

Hassan, S. S. (2000). Determinants of market competitiveness in an environmentally sustainable tourism industry. Journal of travel research, 38(3), 239-245. http://dx.doi.org/10.1177/004728750003800305

Heath, E. (2003). Key trends and challenges in destination marking: the need for a new paradigm. In J. Ruddy, \& S. Flanagan (Eds), Tourism destination marketing: Gaining the competitive edge (pp. 174-196). Dublin, Ireland: Travel and Tourism Research Association.

Hossain, M. J. (2006). The use of promotional activities in the tourism industry: The case of Bangladesh (Unpublished Master Thesis). Business Administration, School of Management, Blekinge Institute of Technology, Sweden. Retrieved from http://www.bth.se/fou/cuppsats.nsf/all/3c5d92da5330a8eec 12571950033b0b8?OpenDocument

Huang, S. L. (2011). Golf event sports tourists: Behavioral intentions and perceptions of service quality, value, satisfaction, and image (Unpublished Doctoral Dissertation). Hospitality Administration, Texas Tech University. Retrieved August 23, 2015 from https://repositories.tdl.org/ttuir/bitstream/handle/2346/ 45264/Huang_DissertationReview.pdf?sequence=1

Hudson, S., Ritchie, B., \& Timur, S. (2004). Measuring destination competitiveness: An empirical study of Canadian ski resorts. Tourism and Hospitality Planning \& Development, 1(1), 79-94. http://dx.doi.org/10.1080/1479053042000187810

Huh, J. (2002). Tourist satisfaction with cultural/heritage site: The Virginia Triangle (Unpublished Master's Thesis). Faculty of Virginia Polytechnic Institute and State University, Blacksburg, Virginia. Retrieve May 8, 2015 from http://www.scholar. lib.vt.edu/thesis/available/etd01540021710/unrestrited/thesis.pdf.

Inskeep, E. (1991). Tourism planning: An integrated and sustainable development approach. John Wiley \& Sons, New York.

Jamaludin, M., Johari, S., Aziz, A., Kayat, K., \& Mohamad Yusof, A. R. (2012). Examining structural relationship between destination image, tourist satisfaction and destination loyalty. International Journal of Independent Research and Studies -IJIRS, 1(3), 89-96. 
Khound, J. M. (2013). Constraints and prospects of rural tourism development: An overview of tourism in Shyamgaon of Titabor of Jorhat, District (Assam). Journal of Tourism and Hospitality Management, 1(1), 27-31.

Komppula, R. (2014). The role of individual entrepreneurs in the development of competitiveness for a rural tourism destination-A case study. Tourism Management, 40, 361-371.

Kozak, M. (1999). Destination competitiveness measurement: Analysis of effective factors and indicators. Paper presented at European Regional Science Association (ERSA) Conference, Vienna, Austria. Retrieved 9 June 2015 from http://wwwsre.wuwien.ac.at/ersa/ersaconfs/ersa99/Papers/a289.pdf

Kozak, M., Baloğlu, Ş., \& Bahar, O. (2009). Measuring destination competitiveness: Multiple destinations versus multiple nationalities. Journal of Hospitality Marketing \& Management, 19(1), 56-71. http://dx.doi.org/10.1080/ 19368620903327733

Kozak, M., \& Rimmington, M. (1999). Measuring tourist destination competitiveness: Conceptual considerations and empirical findings. International Journal of Hospitality Management, 18, 273-283. http://dx.doi.org/10.1016/S02784319(99)00034-1

Kumra, R. (2008). Service quality in rural tourism: A prescriptive approach. Paper presented in Conference on Tourism in India- Challenges Ahead, 15th-17th May 2008, Indian Institute of Management Kozhikode. Retrieved 23 November 2015 from http://www.researchgate.net/publication/ 255592421_Service_Quality_in_ Rural_Tourism_A_Prescriptive_Approach

Lawson, R., Merrett, T., \& Williams, J. (1996). The social impacts of tourism a review of the literature with special emphasis on New Zealand (pp. 37-45). Wellington: The Group.

Lee K. F., \& Kandasamy, S. (2011). An investigation of service quality and customer satisfaction among hotels in Langkawi. Paper presented at International Conference on Management (ICM 2011) Proceeding, 13-14 June 2011, Penang, Malaysia. Retrieved September 15, 2015 from http://www.internationalconference. com.my/ proceeding/icm2011proceeding/056_168_ICM2011_PG0731_0749_SERVICE_ QUALITY.pdf

Marku, A. M. (2014). Tourism Strategy of Albania. European Scientific Journal, 10(7), 57-66.

McKercher, B., Packer, T., Yau, M. K., \& Lam, P. (2003). Travel agents as facilitators or inhibitors of travel: perceptions of people with disabilities. Tourism Management, 24(4), 465-474. http://dx.doi.org/10.1016/S0261-5177(02)00107-3

Mechinda, P., Serirat, S., Popaijit, N., Lertwannawit, A., \& Anuwichanont, J. (2010). The relative impact of competitiveness factors and destination equity on tourist's loyalty in Koh Chang, Thailand. International Business \& Economics Research Journal (IBER), 9(10), 99-114. http://dx.doi.org/10.19030/iber.v9i10.643

Middleton, V. T. C. (1997). Sustainable tourism: A marketing perspective. In M. J. Stabler (Ed.), Tourism sustainability. Principles to practice (pp. 129-142). Wallingford: CAB International. 
Mihalič, T. (2000). Environmental management of a tourist destination: A factor of tourism competitiveness. Tourism management, 21(1), 65-78. http://dx.doi.org/10.1016/ S0261-5177(99)00096-5

Mihalič, T. (2013). Performance of environmental resources of a tourist destination: Concept and application. Journal of Travel Research, 52(5), 614-630. http://dx.doi.org/10.1177/0047287513478505

Mill, R. C., \& Morrison, A. M. (1992). The tourist system: An introductory text (2nd ed.). Englewood Cliffs, New Jersey: Prentice-Hall.

Mohamed, B., Malek, A., \& Irwana Omar, S. (2015). Perception of destination competitiveness: Lesson to BIMP-EAGA Region. BIMP-EAGA Journal for Sustainable Tourism Development, 1(1), 55-69.

Murphy, K. J. (1985). Corporate performance and managerial remuneration: An empirical analysis. Journal of Accounting and Economics, 7(1), 11-42. http://dx.doi. org/10.1016/0165-4101(85)90026-6

Murphy, P., Pritchard, M. P., \& Smith, B. (2000). The destination product and its impact on traveller perceptions. Tourism management, 21(1), 43-52. http://dx.doi. org/10.1016/S0261-5177(99)00080-1

Nunnally, J. C. (1978). Psychometric theory. New York, NY: McGraw-Hill.

Omerzel, D. G. (2006). Competitiveness of Slovenia as a tourist destination. Managing Global Transitions, 4(2), 167-189.

Parahiyanti, C. R., \& Hussein, A. S. (2015). The role of event brand awareness in creating event brand image, event brand quality, and revisit Intention (a Lesson from Ijen Car Free Day). Jurnal Ilmiah Mahasiswa FEB, 3(2), 1-11.

Perles-Ribes, J. F., Ramón-Rodríguez, A. B., \& Sevilla-Jiménez, M. (2014). Market share as a tourist destinations competitiveness measure: Sense and limitations. Cuadernos de Turismo, 34, 423-425.

Pikkemaat, B., \& Müller, S. (2008). Consumer changes in secular behaviour. In C. Kronenberg, S. Müller, M. Peters, B. Pikkemaat, \& K. Weiermair (Eds.), Change management in tourism: From 'old' to 'new' tourism (pp. 69-83). Berlin: ESV.

Presenza, A., Sheehan, L., \& Ritchie, J. B. (2005). Towards a model of the roles and activities of destination management organizations. Journal of Hospitality, Tourism and Leisure Science, 3(1), 1-16.

Rajesh, R. (2013). Impact of tourist perceptions, destination image and tourist satisfaction on destination loyalty: A conceptual model. Special Issue, 11(3), 67-78.

Ramakumar, A., \& Rajashree, S. (2008). Product development and management in rural tourism: Tourism in India- challenges Ahead. Paper presented at the Indian Institute of Management Kozhikode (IIMK) 2008, 15-17 May, 2008, Kozhikode, Kerala, India. Retrieved from http://dspace.iimk.ac.in/bitstream/2259/ 585/1/443-452+Prof.+A.Ramakumar.pdf

Reichheld, F. F., \& Schefter, P. (2000). E-loyalty: your secret weapon on the web. Harvard Business Review, 78(4), 105-113.

Ritchie, J. R., \& Crouch, G. I. (1993). Competitiveness in international tourism: A framework for understanding and analysis. Canada: World Tourism Education and Research Centre, University of Calgary. 
Ritchie, J. R., \& Crouch, G. I. (2010). A model of destination competitiveness/sustainability: Brazilian perspectives. Revista de Administracao Publica, 44(5), 1049-1066. http://dx.doi.org/10.1590/S0034-76122010000500003

Ross, E. L. D., \& Iso-Ahola, S. E. (1991). Sightseeing tourists" motivations and satisfaction. Annals of Tourism Research, 18(2), 226-237.

Said, A., Shuib, A., Ayob, N., \& Yaakob, F. (2013). An evaluation of service quality from visitors' perspectives: The case of Niah National Park in Sarawak. International Journal of Business and Society, 14(1), $61-78$

Sarawak Forestry Corporation. (n. d.). Kubah National Park. Retrieved Jan 27, 2016 from http://www.sarawakforestry.com/htm/snp-np-kubah.html

Schefter, P., \& Reichheld, F. (2000). E-loyalty: Your secret weapon on the Web. Harvard Business Review, 78(4), 105-113.

Shonk, D. J. (2006). Perceptions of service quality, satisfaction and intent to return among tourists attending a sporting event (Unpublished Doctoral Dissertation). The Ohio State University, Columbus. Retrieved March 13, 2015 from https://etd.ohiolink. edu/rws etd/document/get/osu1148617265/inline

Tenenhaus, M., Vinzi, V. E., Chatelin, Y. M., \& Lauro, C. (2005). PLS path modeling. Computational Statistics and Data Analysis, 48(1), 159-205. http://dx.doi. org/10.1016/j.csda.2004.03.005

Thyne, M., Lawson, R., \& Todd, S. (2006). The use of conjoint analysis to assess the impact of the cross-cultural exchange between hosts and guests. Tourism Management, 27(2), 201-213. http://dx.doi.org/10.1016/j.tourman.2004.09.003

Tsai, H., Song, H., \& Wong, K. K. (2009). Tourism and hotel competitiveness research. Journal of Travel \& Tourism Marketing, 26(5-6), 522-546. http://dx.doi. org/10.1080/10548400903163079

Tubey, W., \& Tubey, R. J. (2014). Resources and attractions for sports tourism in north rift region in Kenya. Journal of Economics and Sustainable Development, 5(23), $170-176$.

Vengesayi, S. (2003). A conceptual model of tourism destination competitiveness and attractiveness. Paper presented at Australian and New Zealand Marketing Academy Conference (ANZMAC) 2003, Adelaide, Australia. Retrieved from http://195.130.87.21:8080/dspace/bitstream/123456789/523/ $1 / \mathrm{A} \% 20$ conceptual $\% 20$ mode $1 \% 20$ of\%20tourism $\% 20$ destination $\% 20$ competitiveness $\% 20$ and $\% 20$ attractiveness.pdf

Wani, N. A., \& Shafi, A. (2013). Rural tourism: An option for development of rural economy in Kashmir. International Journal of Innovative Research \& Development, 2(6), 852-861.

Wetzels, M., Schroder, G. O., \& Oppen, V. C. (2009). Using PLS path modeling for assessing hierarchical construct models: Guidelines and empirical illustration. MIS Quarterly, 33(1), 177-195.

Wilde, S. J., \& Cox, C. (2008). Linking destination competitiveness and destination development: Findings from a mature Australian tourism destination. Paper presented at Proceedings of the Travel and Tourism Research Association (TTRA) European Chapter Conference-Competition in tourism: Business and destination perspectives, Helsinki, Finland, 467-478. 
Yoon, Y. (2002). Development of a structural model for tourism destination competitiveness from stakeholders' perspectives (Doctoral Dissertation). Hospitality and Tourism Management, Faculty of the Virginia Polytechnic Institute and State University. Retrieved March 4, 2016 from https://theses.lib. vt.edu/theses/available/etd-10032002-165524/unrestricted/Tourism DestinationCompetitiveness YooshikYoon.pdf

Yoon, Y., \& Uysal, M. (2005). An examination of the effects of motivation and satisfaction on destination loyalty: A structural model. Tourism management, 26(1), 45-56. http://dx.doi.org/10.1016/j.tourman.2003.08.016

Zhang, J., Inbakaran, R. J., \& Jackson, M. S. (2006). Understanding community attitudes towards tourism and host-guest interaction in the urban-rural border region. Tourism Geographies, 8(2), 182-204. http://dx.doi.org/10.1080/14616680 600585455

Zhu, M. F. (2011). Examining the structural relationships of tourist characteristics and destination satisfaction. International Conference on E-business, Management and Economics, IPEDR, 3, 187-191. 